\title{
Selection and identification of non-pathogenic bacteria isolated from fermented pickles with antagonistic properties against two shrimp pathogens
}

\author{
Hadi Zokaeifar ${ }^{1}$, José Luis Balcázar ${ }^{2}$, Mohd Salleh Kamarudin ${ }^{1}, \operatorname{Kamaruzaman~Sijam}^{3}$, Aziz Arshad ${ }^{1}$ \\ and Che Roos Saad ${ }^{1}$
}

In this study, potential probiotic strains were isolated from fermented pickles based on antagonistic activity against two shrimp pathogens (Vibrio harveyi and Vibrio parahaemolyticus). Two strains L10 and G1 were identified by biochemical tests, followed by $16 \mathrm{~S}$ ribosomal RNA gene sequence analysis as Bacillus subtilis, and characterized by PCR amplification of repetitive bacterial DNA elements (Rep-PCR). Subsequently, B. subtilis L10 and G1 strains were tested for antibacterial activity under different physical conditions, including culture medium, salinity, $\mathrm{pH}$ and temperature using the agar well diffusion assay. Among the different culture media, LB broth was the most suitable medium for antibacterial production. Both strains showed the highest level of antibacterial activity against two pathogens at $30^{\circ} \mathrm{C}$ and $1.0 \% \mathrm{NaCl}$. Under the $\mathrm{pH}$ conditions, strain $\mathrm{G} 1$ showed the greatest activity against $V$. harveyi at $\mathrm{pH}$ 7.3-8.0 and against $V$. parahaemolyticus at $\mathrm{pH}$ 6.0-8.0, whereas strain L10 showed the greatest activity against two pathogens at $\mathrm{pH}$ 7.3. The cell-free supernatants of both strains were treated with four different enzymes in order to characterize the antibacterial substances against $V$. harveyi. The result showed considerable reduction of antibacterial activity for both strains, indicating the proteinaceous nature of the antibacterial substances. A wide range of tolerance to $\mathrm{NaCl}, \mathrm{pH}$ and temperature was also recorded for both strains. In addition, both strains showed no virulence effect in juvenile shrimp Litopenaeus vannamei. On the basis of these results and safety of strains to $L$. vannamei, they may be considered for future challenge experiments in shrimp as a very promising alternative to the use of antibiotics. The Journal of Antibiotics (2012) 65, 289-294; doi:10.1038/ja.2012.17; published online 11 April 2012

Keywords: antibacterial activity; aquaculture; Bacillus subtilis; probiotics; shrimp; vibriosis

\section{INTRODUCTION}

The development of aquaculture industry has been accompanied by the emergence of a large variety of pathogens. Bacterial species such as Vibrio alginolyticus, Vibrio anguillarum, V. harveyi, V. parahaemolyticus and Vibrio vulnificus have been associated with high mortalities in fish and shellfish facilities. ${ }^{1-3}$ Prevention and control of diseases has led to a substantial increase in the use of chemotherapeutic agents. However, the utility of these agents as a preventive measure has been questioned, given the increasing concern about antibiotic resistance genes in bacteria. ${ }^{4,5}$ Thus, the use of probiotic is receiving considerable attention as an alternative to control infections. ${ }^{6-8}$ Probiotics are defined as 'live microorganisms, which when administered in adequate amounts confer a health benefit to the host. ${ }^{9}$

The range of probiotic examined for use in aquaculture encompasses both Gram-negative and Gram-positive bacteria, although the use of other organisms such as bacteriophages, yeasts and unicellular algae has also been explored.,10 The genus Bacillus has been reported as beneficial bacteria for aquaculture. In this regard, administration of
Bacillus has shown beneficial effects on growth performance, survival rate and immune response of black tiger shrimp, Penaeus monodon. ${ }^{11,12}$ For instance, B. subtilis UTM 126 isolated from shrimp culture pond, produced antibacterial activity against Vibrio species. ${ }^{13}$ Another study showed that B. subtilis E20, isolated from fermented soybean, improved the immunity of white shrimp (L. vannamei) and resistance to the pathogen V. alginolyticus. ${ }^{14}$

A common way to select probiotics is to perform identification of candidate bacteria and in vitro antagonism tests, in which pathogens are exposed to the candidate probiotics or their extracellular products. ${ }^{5,15}$ However, antagonist activity is highly dependent on environmental factors and could be disturbed by physical conditions. Furthermore, resistance to acidic conditions is important for potential probiotics to survive and grow in the gastrointestinal tract.

Given this, the aim of this study was to isolate and identify beneficial bacteria from fermented pickles for potential application as probiotics in shrimp facilities. Several tests of probiotic efficacy were used, including antagonistic activity against two shrimp pathogens

${ }^{1}$ Department of Aquaculture, Faculty of Agriculture, Universiti Putra Malaysia, Serdang, Malaysia; ${ }^{2}$ Catalan Institute for Water Research (ICRA), Scientific and Technological Park of the University of Girona, Girona, Spain and ${ }^{3}$ Department of Plant Protection, Faculty of Agriculture, Universiti Putra Malaysia, Serdang, Malaysia 
and different physical conditions for maximum antibacterial production. In addition, the sensitivity of antibacterial substances to different enzymes and the safety of candidate strains for juvenile shrimp, L. vannamei, were investigated.

\section{MATERIALS AND METHODS}

Isolation and screening for antibacterial activity

Garlic, cabbage, carrot and vinegar were purchased from a local market at Serdang, Selangor, Malaysia. They were washed with distilled water and heated at $60{ }^{\circ} \mathrm{C}$ for $10 \mathrm{~min}$. After drying for $10 \mathrm{~min}$, all the ingredients were mixed and covered with liquid containing $30 \%$ vinegar and $70 \%$ salt water $(1 \% \mathrm{NaCl})$. The container was sealed and kept for fermentation for 3 months. After the fermentation, bacteria were isolated from the ingredients and liquids. Briefly, the ingredients were separated, homogenized, and serially 10 -fold diluted in phosphate-buffered saline solution (PBS; pH 6.6). One hundred microliters of each dilution was then plated on nutrient agar (NA) supplemented with $2 \%$ $\mathrm{NaCl}$ and incubated at $30^{\circ} \mathrm{C}$ for $24-48 \mathrm{~h}$. Single colonies were replicaplated ${ }^{4}$ onto plates containing $10 \mathrm{ml}$ Muller Hinton agar supplemented with $1 \% \mathrm{NaCl}$ and $V$. harveyi, which was previously grown overnight in LB broth (Difco, Spark, NV, USA). Plates were then incubated for $24 \mathrm{~h}$ at $30^{\circ} \mathrm{C}$. Clear zones around replica-plated bacteria were interpreted as antagonistic activity against the pathogen and they were picked from the original plates. Antagonistic strains were stored in glycerol at $-80^{\circ} \mathrm{C}$ for further investigation.

\section{Agar well diffusion assay}

Antagonistic strains were re-examined against $V$. harveyi (ATCC 14126, ATCC, Manassas, VA, USA) and V. parahaemolyticus (ATCC 43996) using the agar well diffusion assay to confirm the antagonistic ability. Previous studies have demonstrated that both species are important pathogenic bacteria for aquaculture. ${ }^{16,17}$ Antagonistic strains were grown in LB broth at $30^{\circ} \mathrm{C}$ for 48-96h. After incubation, the bacterial suspensions were removed by centrifugation and culture supernatants were sterilized by passage through $0.20 \mu \mathrm{m}$-pore-size filters (Sartorius, Goettingen, Germany). The target Vibrio strains were grown overnight in $10 \mathrm{ml}$ of $\mathrm{LB}$ broth at $30^{\circ} \mathrm{C}$, and $10 \mu \mathrm{l}$ of each Vibrio was mixed into $10 \mathrm{ml}$ of melted Muller Hinton agar supplemented with $2 \% \mathrm{NaCl}$. Wells were then punched $(5 \mathrm{~mm})$ into the agar and $25 \mu \mathrm{l}$ of sterilefiltered supernatants were added. Plates were incubated at $30^{\circ} \mathrm{C}$ and observed for clearing zones around the wells after $24 \mathrm{~h}$. Sterile LB broth was used as control.

\section{Identification of bacterial strains}

In order to identify and differentiate both strains, conventional and molecular identification were performed. After the Gram-staining and morphological characteristics, strains were subjected to phenotypic tests for conventional identification, including catalase, oxidase, motility, urease, ONPG, citrate, indole, Voges-Proskauer, $\mathrm{H}_{2} \mathrm{~S}$ production, glucose, inositol, mannitol and reduction ability of nitrate to nitrite.

Extraction and amplification of genomic DNA for 16S rRNA sequence analysis were carried out as described previously. ${ }^{18}$ The sequences obtained were compared against the sequences available in the GenBank, EMBL and DDBJ databases obtained from the National Center for Biotechnology Information using the BLASTN. ${ }^{19}$

To differentiate and characterize both strains, Rep-PCRs with Rep, Eric and BOX primers were performed. The DNA amplification was followed according to the previous study. ${ }^{20}$ The annealing temperatures were selected based on the oligonucleotide primers, Rep-PCR $\left(40^{\circ} \mathrm{C}\right)$, Eric-PCR $\left(51^{\circ} \mathrm{C}\right)$ and BOX-PCR $\left(53^{\circ} \mathrm{C}\right)$. PCR reaction for each type of primers without DNA template was performed as control. All PCR reactions were performed in triplicate. A total of $12 \mu \mathrm{l}$ of PCR amplification products was verified by $2.0 \%(\mathrm{w} / \mathrm{v})$ agarose gel electrophoresis stained with ethidium bromide for $3.5 \mathrm{~h}$ with $65 \mathrm{~V}$, and photographed under UV illumination. Both $1 \mathrm{~kb}$ and $100 \mathrm{bp}$ ladders were used as markers.

Effect of culture medium composition on the antibacterial activity Antibacterial production was estimated using four different culture media including LB broth, marine broth (MB), nutrient broth (NB) and Muller
Hinton broth (MHB) (Difco), supplemented with $1 \%$ glucose and without glucose. To evaluate the antibacterial production, $50 \mu \mathrm{l}$ of a bacterial suspension was inoculated into each culture medium and then incubated at $30^{\circ} \mathrm{C}$ for $72 \mathrm{~h}$. All culture media had an initial $\mathrm{pH}$ of 6.6. Antibacterial activity of bacterial strains in the different culture media was determined using the agar well diffusion assay, as described above.

Effect of $\mathrm{pH}$, salinity and temperature on the antibacterial activity The optimal condition for maximum antibacterial production was assessed by growing the bacterial strains into LB broth at different $\mathrm{pH}(6,6.6,7.3,8$ and $8.8)$, salinity $(0,1,2$, and $3 \%)$ and temperature $\left(25,30,35\right.$ and $\left.40{ }^{\circ} \mathrm{C}\right)$ levels for $96 \mathrm{~h}$. Two milliliters of each grown culture was collected every $24 \mathrm{~h}$, and the antagonistic activity against $V$. harveyi and $V$. parahaemolyticus was determined using the agar well diffusion assay.

\section{Spectrophotometric assay upon antibacterial activity}

Bacterial strains were grown in $50 \mathrm{ml} \mathrm{LB}$ broth at the optimal condition obtained by the previous assays. The inhibitory activity of sterile-filtered supernatants from each bacterial strain was tested by adding $50 \mathrm{ml}$ overnight cultures of $V$. harveyi or V. parahaemolyticus, previously grown in $\mathrm{MH}$ broth. Samples were collected every $6 \mathrm{~h}$, and the growth of two shrimp pathogens was monitored by measuring optical density at $600 \mathrm{~nm}\left(\mathrm{OD}_{600}\right)$ with a spectrophotometer. Each treatment was tested in triplicate. Penicillin and LB broth were used as positive and negative control, respectively.

\section{Characterization of the antibacterial substances}

Sterile-filtered supernatants of both strains were treated with proteinase $\mathrm{K}$ $\left(1 \mathrm{mg} \mathrm{ml}^{-1}, 37^{\circ} \mathrm{C}\right)$, trypsin $\left(50 \mathrm{mg} \mathrm{ml}^{-1}, 37^{\circ} \mathrm{C}\right), \alpha$-amylase $\left(1 \mathrm{mg} \mathrm{ml}^{-1}, 25^{\circ} \mathrm{C}\right)$, and lysozyme $\left(1 \mathrm{mg} \mathrm{m}^{-1}, 25^{\circ} \mathrm{C}\right)$ in order to characterize the antibacterial substances. After incubation for $1 \mathrm{~h}$, antibacterial activity of both strains was tested against $V$. harveyi, using well-diffusion agar assay. The residual activity was measured. Sterile-filtered supernatants without enzyme treatment were considered as control. The assay was repeated two times to ensure the reproducibility.

\section{Tolerances of antagonistic strains under different conditions}

Tolerance to different $\mathrm{pH}$, salinity and temperature levels was assessed by culturing the antagonistic strains in NA. Tolerance to temperature was determined by incubating the inoculated NA at $4,10,20,30,40,50,60$ and $70{ }^{\circ} \mathrm{C}$. Tolerance to salinity was determined with or without the addition of $\mathrm{NaCl}$ at different concentrations (from 1 to $10 \%$ ) to NA cultures, and examining the growth after $24-48 \mathrm{~h}$. To determine the $\mathrm{pH}$ tolerance, the antagonistic strains were inoculated on $\mathrm{NA}$ at $\mathrm{pH} 3,4,5,6,7,8,9,10$ and 11 adjusted with $1 \mathrm{~N} \mathrm{NaOH}$ or $1 \mathrm{~N} \mathrm{HCl}$. All treatments were carried out in triplicate.

\section{Safety of candidate strains to L. vannamei}

In order to demonstrate the safety of both strains to shrimp, an experiment was conducted using juvenile shrimps L. vannamei, at Marine Science Research Station, UPM, Port Dickson, Malaysia. Shrimp had not been exposed to shrimp diseases and were deemed pathogen-free by appearances and standard microbiological techniques. Healthy juveniles weighing approximately $3 \mathrm{~g}$ were acclimatized for 4 days in $20 \mathrm{ppt}$ seawater. Shrimps were then distributed into20-1 glass tanks of 10 animals each with a constant aeration. Two groups of shrimp were injected with $0.1 \mathrm{ml}$ of $10^{10} \mathrm{cfu} \mathrm{ml}^{-1}$ of B. subtilis strains L10 and G1. The third group was shrimp injected with $0.1 \mathrm{ml}$ of sterile PBS as control. All shrimps were injected at the third abdominal segment using $1 \mathrm{ml}$ sterile insulin syringe $(29 \mathrm{G})$. In addition, all experiments were performed in triplicate. One shrimp was collected randomly from each tank at the beginning and the end of the experiment to evaluate the concentration of B. subtilis. Shrimps were collected in cooled-sterile PBS and homogenized in a glass homogenizer immediately after they were killed. Pooled technique was performed for each treatment. Homogenized and pooled samples were serially diluted in 10-fold steps in PBS, and $100 \mu$ of each dilution spread on Mannitol Egg Yolk Polymyxin agar (MYP agar, Difco) plates to estimate the 
concentration of $B$. subtilis species $\left(\mathrm{cfu} \mathrm{g}^{-1}\right)$. All yellow colonies were counted in plates containing the total amount of 30-300 cfu. Shrimps were fed with the commercial pellet feed (BLANCA, Berangan, Malaysia) and 50\% of the water was exchanged daily. Shrimps were monitored daily for any mortality or signs of weakness for up to 15 days.

\section{Statistical Analysis}

In order to obtain the best physical conditions for maximum antibacterial production against two shrimp pathogens, the data were analyzed by repeated measure analysis of variance and the means were compared by least significant difference (LSD) test. All statistics were performed using the SPSS 14.0 for Windows (SPSS, Chicago, IL, USA).

\section{RESULTS AND DISCUSSION}

In selecting a potential probiotic strain for beneficial health effects on the host, many criteria must be considered. In order to colonize the gastrointestinal tract, potential probiotics should produce antibacterial substances against pathogens and express high tolerance to acidic conditions. Although isolation and screening of potential probiotics is usually a long process and time-consuming, the replica-plating method could be used successfully for the isolation of bacterial strains with antibacterial properties. ${ }^{4}$ In the present study, the isolation process of antagonistic strains using replica-plating method was quick and successfully performed.

\section{Isolation and identification of antagonistic strains}

A total of 89 colonies were isolated from fermented pickles, including 43,25 and 21 colonies from vinegar, garlic and cabbage, respectively. They were tested for their possibility of antibacterial activity against $V$. harveyi using the replica-plating method. Overall, 14 bacterial strains produced clearing zones of different size. Out of 14 antagonistic strains, only two strains displayed strong inhibitory activity against $V$. harveyi and $V$. parahaemolyticus in the agar well diffusion assay.

The same pattern of biochemical reaction was observed for both antagonistic strains. Both strains were Gram-positive, rod-shaped cells, motile, oxidase, catalase, urease, ONPG, Voges-Proskauer, citrate and mannitol positive. Ability to reduce nitrate to nitrite and starch hydrolysis were recorded for both strains. Indole, inositol and glucose fermentation was negative and unable to produce $\mathrm{H}_{2} \mathrm{~S}$.

PCR amplification using universal primers amplified a fragment of the expected size $(900 \mathrm{bp})$ from the $16 \mathrm{~S}$ rRNA gene. PCR product were purified and sequenced to identify the antagonistic strains. Strain G1 (GenBank accession number HQ731482) was identified with $100 \%$ similarity as B. subtilis subsp. spizizenii NRRL B-23049 . Strain L10 (GenBank accession number HQ731481) exhibited 99.89, 99.77 and $99.73 \%$ similarity to B. subtilis subsp. spizizenii NRRL B-23049 ${ }^{\mathrm{T}}$, Brevibacterium halotolerans LMG $21660^{\mathrm{T}}$ and Bacillus tequilensis NRRL B-41771 ${ }^{\mathrm{T}}$, respectively (Supplementary material, Table S1).

Genomic DNA fingerprinting based on Rep-PCR characterizes and distinguishes bacterial strains rapidly. In this study, DNA fingerprint produced by Rep-PCR method (REP, ERIC and BOX) distinguished B. subtilis strains. Although Rep-PCR revealed a very similar pattern for both strains, the results of BOX-PCR and ERIC-PCR showed higher discriminatory power (Figure 1).

\section{Optimal physical conditions for antibacterial production}

The culture conditions influence the formation and production of antibacterial substances. Antibacterial production was not detected when two $B$. subtilis strains were grown in culture media supplemented with $1 \%$ glucose. Similar results were reported ${ }^{21}$ with addition of high level $(>0.5 \%)$ of glucose, which might be due to catabolite repression of the production of Bacillus licheniformis by glucose. In addition, the greatest inhibition zones against $V$. harveyi were recorded in LB broth, followed by MHB, MB and NB (Table 1). LB broth was, therefore, selected as the best culture medium for further assays.

The two B. subtilis strains were tested under different salinity levels. The maximum antibacterial production $(P<0.05)$ against $V$. harveyi and $V$. parahaemolyticus was observed at $1 \% \mathrm{NaCl}$ after $72 \mathrm{~h}$ for strain L10 and after $96 \mathrm{~h}$ for strain G1 (Figures 2 and 3). Alteration of $\mathrm{pH}$ had a significant effect $(P<0.05)$ on antibacterial production. Antagonistic activity of $B$. subtilis strain L10 was higher $(P<0.05)$ at $\mathrm{pH} 7.3$ after 72 and $96 \mathrm{~h}$ against $V$. harveyi and $V$. parahaemolyticus, respectively. B. subtilis strain G1 showed the greatest antagonistic activity at $\mathrm{pH} 7.3$ and $8.0(P<0.05)$ after 72 to 96 h against $V$. harveyi, whereas the highest activity $(P<0.05)$ against $V$. parahaemolyticus was exhibited at $\mathrm{pH} 6$ and 8 after $96 \mathrm{~h}$ of incubation (Figures 2 and 3).

At the final stage of the experiment, LB broth was prepared based on the optimal conditions of salinity and $\mathrm{pH}$, and the inoculated bacteria were tested at different temperatures. The highest value $(P<0.05)$ of clearing zone for B. subtilis L10 and G1 strains against two pathogens was at $30^{\circ} \mathrm{C}$ after $96 \mathrm{~h}$ of incubation (Figures 2 and 3) and (Supplementary material, Figure S1).

In terms of $\mathrm{pH}$ and temperature, the maximum antibacterial activity in this study was found in accordance with the suitable range for shrimp culture suggested by previous studies. ${ }^{22,23}$ Appropriate $\mathrm{NaCl}$ concentration for shrimp culture specially $L$. vannamei has been suggested previously at $10-15$ ppt. ${ }^{23}$ In this study, both strain showed the highest antibacterial activity at $1 \%$ salinity. However, the existence of antibacterial potential at $1 \%$ salinity might be efficient to suggest both candidate bacteria for in vivo experiment in culture with L. vannamei.

\section{Spectrophotometric assay}

Antibacterial activity of the strains was spectrophotometrically tested in $\mathrm{MH}$ broth prepared at the optimal conditions for antibacterial production. The two B. subtilis strains showed a stable activity to control the proliferation of both pathogens, $V$. harveyi and $V$. parahaemolyticus, ranging from approximately 0.6 to 0.8 OD after $24 \mathrm{~h}$. The population of both pathogens increased in the negative controls for $24 \mathrm{~h}$ of challenge, ranging from 0.6 to 1.4 OD. However, bacterial pathogens treated with penicillin as positive control showed significant decreasing of population, ranging from 1 to $0.4 \mathrm{OD}$ and 1.1 to 0.4 OD for $V$. harveyi and $V$. parahaemolyticus, respectively (Figure 4). Considering the optimal condition for antibacterial production which is in accordance with shrimp culture condition, both strains might be successful when administered as probiotic for in vivo experiment.

\section{Characterization of the antibacterial substances}

Bacteria are able to produce variety of antibacterial substances with a wide range of activities. Antimicrobial peptides such as bacteriocins or bacteriocin-like substances are considered among the most essentials because of being inexpensive, effective and non-toxic to animals and human. ${ }^{24-26}$ In fact, Bacillus spp. has been reported as one of the major producers of proteinaceous substances. ${ }^{27}$ In this study, the antibacterial activity of sterile-filtered supernatants obtained from both strains was considerably reduced after being treated with enzymes (Table 2). These results indicate the 
a

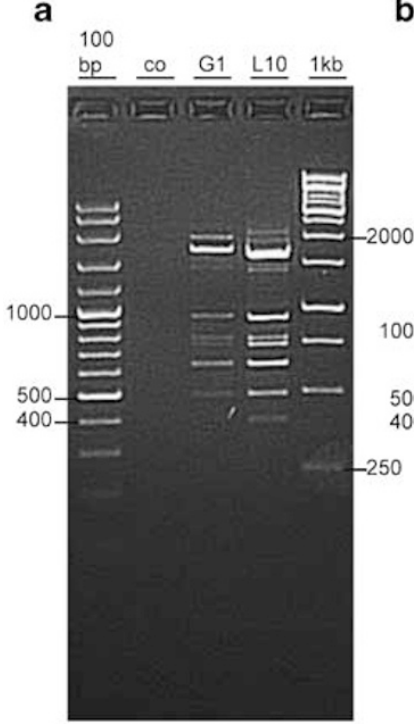

100

bp $\mathrm{co} \quad \mathrm{G} 1 \quad \mathrm{~L} 10 \quad 1 \mathrm{~kb}$ c

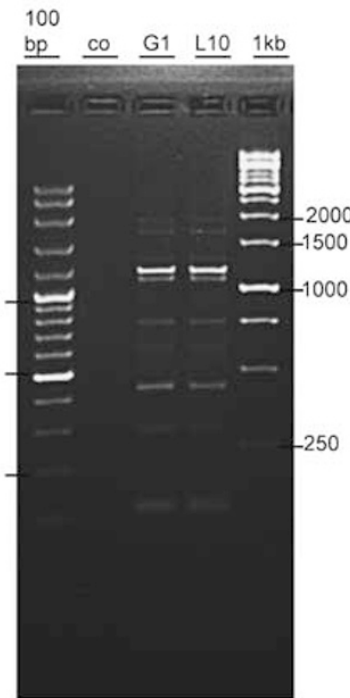

Figure 1 Rep-PCR patterns of both B. subtilis strains, L10 and G1, (a) BOX, (b) ERIC and (c)REP. 100 bp and 1 kb ladders were used as markers. Co denotes control for each PCR reaction (without DNA template).

Table 1 Antagonistic activity of the strains in different culture media against $V$. harveyi

\begin{tabular}{|c|c|c|c|c|c|c|c|c|}
\hline \multirow[b]{3}{*}{ Incubation period (h) } & \multicolumn{8}{|c|}{ Antagonism activity in different culture media $(\mathrm{mm})$} \\
\hline & \multicolumn{2}{|c|}{ LB broth } & \multicolumn{2}{|c|}{$M H B$} & \multicolumn{2}{|c|}{$M B$} & \multicolumn{2}{|c|}{ NB } \\
\hline & L10 & G1 & L10 & G1 & L10 & G1 & L10 & G1 \\
\hline 48 & ND & ND & ND & ND & ND & ND & ND & ND \\
\hline 72 & 8 & 8 & 6 & 6 & 6 & 6 & 6 & 6 \\
\hline 96 & 9 & 9 & 8 & 7 & 7 & 6 & 6 & 6 \\
\hline
\end{tabular}

Abbreviations: MB, marine broth; MHB, Muller Hinton broth; NB, nutrient broth; ND, Not detected

proteinaceous nature of the antibacterial substances produced by both strains. Therefore, bacteriocins or bacteriocin-like inhibitory substances might be responsible for controlling or inhibiting the two shrimp pathogen bacteria, $V$. harveyi or $V$. parahaemolyticus (Supplementary material, Figure S2).

Tolerances of antagonistic strains under different conditions

The sustainability of probiotic growth under different laboratory conditions is a common practice in order to evaluate the probiotic bacteria. For instance, the tolerance of $B$. subtilis to temperature has been reported ranging from 11 to $52^{\circ} \mathrm{C} .{ }^{28}$ Another evidence demonstrated that $B$. subtilis E20, isolated from fermented soybean, has a broad tolerance for $\mathrm{NaCl}$ levels of $0-9 \%, \mathrm{pH}$ value of $5-10$, and temperatures of $10-50{ }^{\circ} \mathrm{C} .{ }^{29}$ In addition, an in vitro study showed a wide range tolerance of Shewanella algae to $\mathrm{pH}, \mathrm{NaCl}$ and temperature, which introduced a good potential probiotic for shrimp aquaculture. ${ }^{30}$ In the present study, the growth of B. subtilis L10 and G1 strains were tested on NA under different culture conditions, including temperature, $\mathrm{pH}$ and salinity. Both strains showed an optimum growth at temperatures between 20 and $50^{\circ} \mathrm{C}$, but not at $4,10,60$ and $70^{\circ} \mathrm{C}$. A wide range of tolerance to $\mathrm{pH}$ was
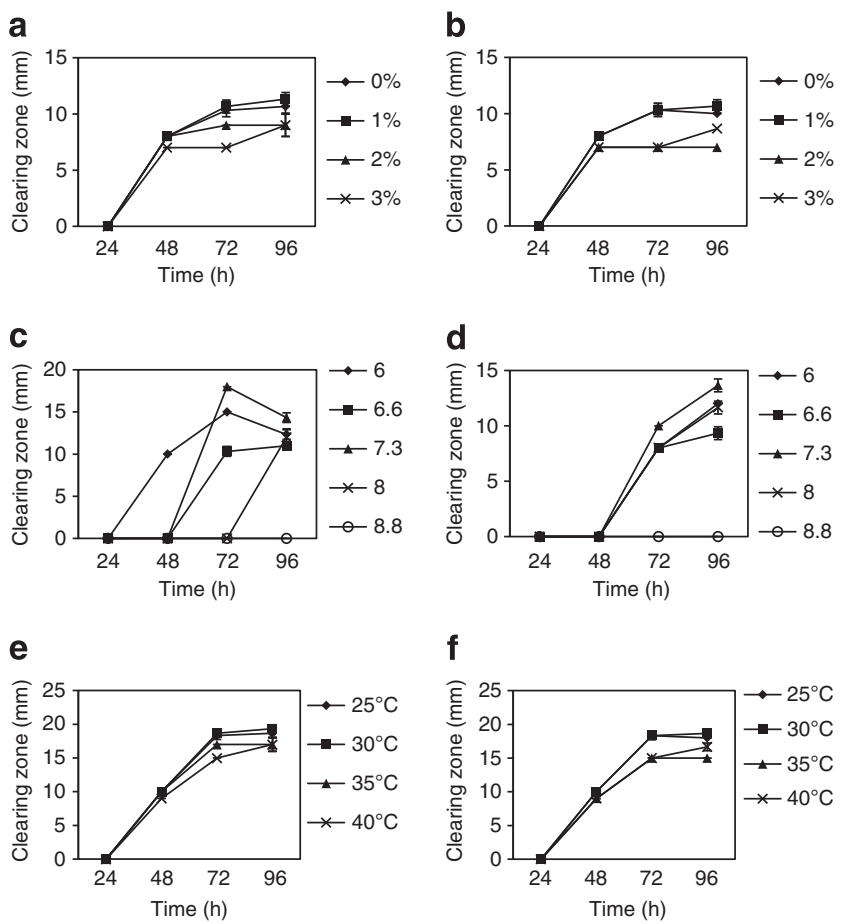

Figure 2 Antagonistic activity of $B$. subtilis L10 at different; (a) salinity against $V$. harveyi; (b) salinity against $V$. parahaemolyticus; (c) $\mathrm{pH}$ against $V$. harveyi; (d) $\mathrm{pH}$ against $V$. parahaemolyticus; (e) temperature against V. harveyi; (f) temperature against V.parahaemolyticus.

observed for both strains, B. subtilis L10 and G1, at pH 4 to 9. In addition, B. subtilis $\mathrm{L} 10$ and G1 strains were able to grow on all tested $\mathrm{NA}$ with $\mathrm{NaCl}$ up to $10 \%$.

\section{Safety of candidate strains to L. vannamei}

Both strains, L10 and G1, were harmless to juvenile shrimp as no mortality was observed in experimental groups, and there was a total 
a

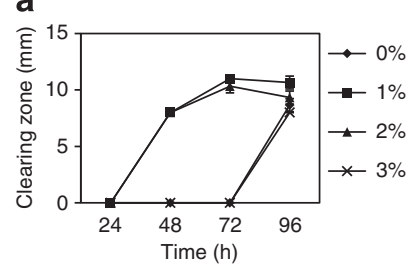

C

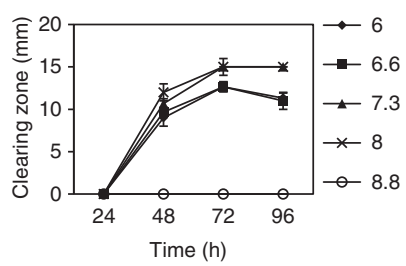

e

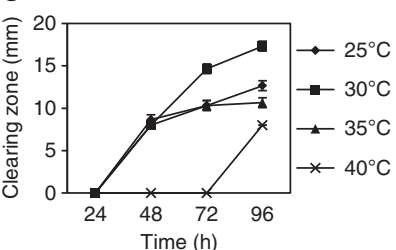

b

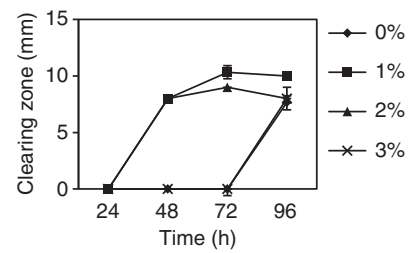

d

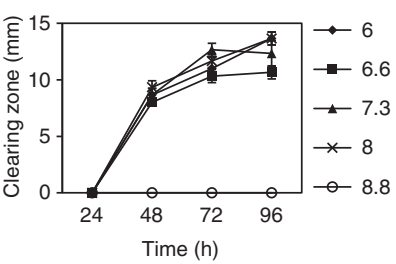

f

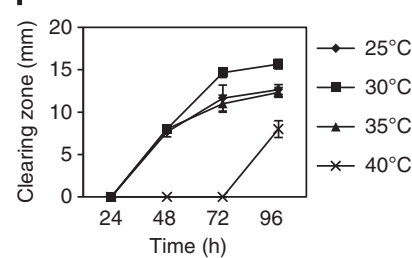

Figure 3 Antagonistic activity of $B$. subtilis G1 at different; (a) salinity against $V$. harveyi; (b) salinity against $V$. parahaemolyticus; (c) $\mathrm{pH}$ against $V$. harveyi; (d) $\mathrm{pH}$ against $V$. parahaemolyticus; (e) temperature against $V$. harveyi; (f) temperature against $V$. parahaemolyticus. a

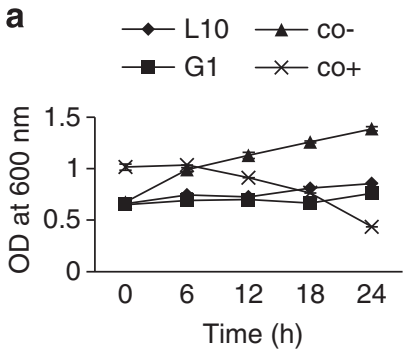

b

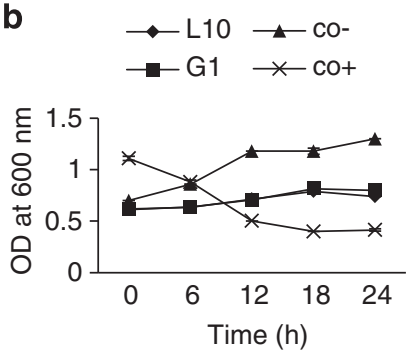

Figure 4 The inhibitory activity of sterile-filtered supernatant from each candidate bacterium at the optimal condition against; (a) V. harveyi; (b) V. parahaemolyticus. Co- presents as negative control (no addition of antibacterial in the broth culture), $\mathrm{Co}+$ presents as positive control (addition of Penicillin in the broth culture). Bars are presented as s.d. generated from replicates.

absence of any disease signs. At the first day of experiment, bacterial counts on MYP agar showed a great number of Bacillus spp. in the body of shrimps treated with both strains compared with control (Figure 5). At day 15 of the experiment, the amount of Bacillus species in the shrimp body were considerably reduced (Figure 5) and no mortality or weakness was recorded. Moreover, the activity and appetite of shrimp treated with candidate strains were not affected as compared with the control group.

On the basis of these results and considering the increasing resistance to antibiotic treatment, B. subtilis L10 and G1 strains might be promising candidate for potential applications against vibriosis in shrimp, as it has been suggested that the gastrointestinal tract is a possible port of entry for $V$. harveyi and $V$. parahaemolyticus ${ }^{31,32}$ as well as a target for protective treatments, such as feeds containing
Table 2 Effect of different enzymes on antibacterial activity of the cell-free supernatants

\begin{tabular}{ccc}
\hline Strain & Treatment & Residual activity (\%) \\
\hline \multirow{2}{*}{ L10 } & Untreated & 100 \\
& Proteinase K & 50 \\
& $\alpha$-Amylase & 71.43 \\
& Trypsin & 42.85 \\
& Lysozyme & 0 \\
G1 & Untreated & 100 \\
& Proteinase K & 77.77 \\
& $\alpha$-Amylase & 83.33 \\
& Trypsin & 55.55 \\
& Lysozyme & 44.44 \\
\hline
\end{tabular}

The cell-free supernatants were treated with enzymes for $1 \mathrm{~h}$ and the residual antibacterial activity (\%) was tested toward $V$. harveyi using well diffusion agar.

Untreated indicates the cell-free supernatant without enzyme treatment.

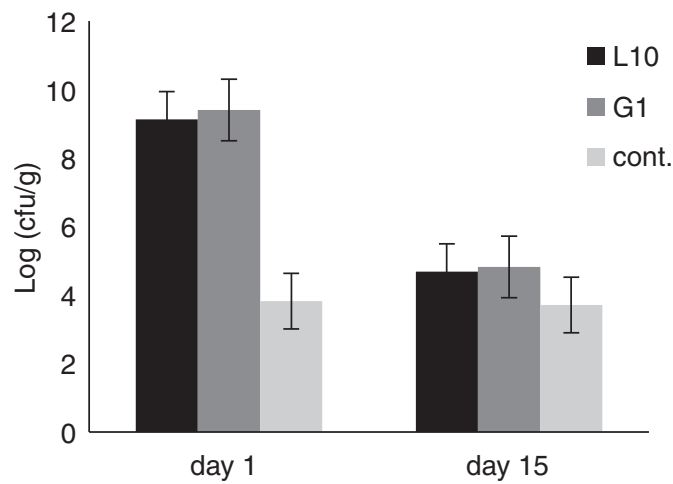

Figure 5 Total $B$. subtilis count using MYP agar at day 1 and 15 of safety experiment. L10, shrimps injected with strain L10 (1010 cfu ml $\left.^{-1}\right)$; G1, shrimps injected with strain $\mathrm{Gl}\left(10^{10} \mathrm{cfu} \mathrm{ml}^{-1}\right)$; Cont., shrimp injected with sterile PBS as control.

probiotic bacteria. ${ }^{33,34}$ Further experiments, including the application of both strains and shrimp challenged with pathogens, could provide valuable information of probiotic potential abilities of these candidates for shrimp aquaculture facilities.

\section{ACKNOWLEDGEMENTS}

We would like to thank the staff of the Laboratory of Microbiology, Department of Plant Protection, Faculty of Agriculture, UPM, for their assistance during this study.

1 Karunasagar, I., Pai, R., Malathi, G. R. \& Karunasagar, I. Mass mortality of Penaeus monodon larvae due to antibiotic-resistant Vibrio harveyi infection. Aquacult 128, 203-209 (1994).

2 Mohney, L. L., Lightner, D. V. \& Bell, T. A. An epizootic of vibriosis in Ecuadorian pondreared Penaeus vannamei Boone (Crustacea: Decapoda). J. World Aquac. Soc. 25, 116-125 (1994).

3 Toranzo, A. E., Magariños, B. \& Romalde, J. L. A review of the main bacterial fish diseases in mariculture systems. Aquacult 246, 37-61 (2005).

$4 \mathrm{Hjelm}, \mathrm{M}$. et al. Selection and identification of autochthonous potential probiotic bacteria from turbot larvae (Scophthalmus maximus) rearing units. Syst. Appl. Microbiol. 27, 360-371 (2004).

5 Balcazar, J. L. et al. The role of probiotics in aquaculture. Vet. Microbiol. 114, 173-186 (2006).

6 Kesarcodi-Watson, A., Kaspar, H., Lategan, M. J. \& Gibson, L. Probiotics in aquaculture: the need, principles and mechanisms of action and screening processes. Aquacult 274, 1-14 (2008).

7 Perez, T. et al. Host-microbiota interactions within the fish intestinal ecosystem. Mucosal Immunol 3, 355-360 (2010) 
8 Merrifield, D. L. et al. The current status and future focus of probiotic and prebiotic applications for salmonids. Aquacult 302, 1-18 (2010).

9 FAO/WHO Report of a joint FAO/WHO expert consultation on evaluation of health and nutritional properties of probiotics in food including powder milk with live lactic acid bacteria. (Cordoba, Argentina, 2001).

10 Irianto, A. \& Austin, B. Probiotics in aquaculture. J. Fish Dis. 25, 633-642 (2002).

11 Rengpipat, S., Phianphak, W., Piyatiratitivorakul, S. \& Menasveta, P. Effects of probiotic bacterium on black tiger shrimp Penaeus monodon survival and growth. Aquacult 167, 301-313 (1998).

12 Rengpipat, S., Rukpratanporn, S., Piyatiratitivorakul, S. \& Menasaveta, P. Immunity enhancement in black tiger shrimp (Penaeus monodon) by a probiont bacterium (Bacillus S11). Aquacult 191, 271-288 (2000).

13 Balcazar, J. L. \& Rojas-Luna, T. Inhibitory activity of probiotic Bacillus subtilis UTM 126 against vibrio species confers protection against vibriosis in juvenile shrimp (Litopenaeus vannamel). Curr. Microbiol. 55, 409-412 (2007).

14 Tseng, D-Y. et al. Enhancement of immunity and disease resistance in the white shrimp, Litopenaeus vannamei, by the probiotic, Bacillus subtilis E20. Fish Shellfish Immunol 26, 339-344 (2009).

15 Verschuere, L., Rombaut, G., Sorgeloos, P. \& Verstraete, W. Probiotic bacteria as biological control agents in aquaculture. Microbiol. Mol. Biol. Rev. 64, 655-671 (2000).

16 Vieira1, F.N. et al. Effect of probiotic supplemented diet on marine shrimp survival after challenge with Vibrio harveyi. Arq. Bras. Med. Vet. Zootec 62, 631-638 (2010).

17 Baffone, W. et al. Occurrence and expression of virulence-related properties by environmental halophilic Vibrio spp. in in vitro and in vivo systems. Food Control 16, 451-457 (2005).

18 Balcazar, J. L., Loureiro, S., Da Silva, Y. J., Pintado, J. \& Planas, M. Identification and characterization of bacteria with antibacterial activities isolated from seahorses (Hippocampus guttulatus). J. Antibiot. 63, 271-274 (2010).

19 Altschul, S. F., Gish, W., Miller, W., Myers, E. W. \& Lipman, D. J. Basic local alignment search tool. J. Mol. Biol. 215, 403-410 (1990).

20 Versalovic, J., Koeuth, T. \& Lupski, J. R. Distribution of repetitive DNA sequences in eubacteria and application to fingerprinting of bacterial genomes. Nucleic Acids Res. 19, 6823-6831 (1991).

21 Pattnaik, P., Grover, S. \& Batish, V. K. Effect of environmental factors on production of lichenin, a chromosomally encoded bacteriocin-like compound produced by Bacillus licheniformis 26L-10/3RA. Microbiol. Res. 160, 213-218 (2005).

22 Kungvankij, P. \& Chua, T. E. Shrimp culture: Pond design, operation and management. (Network of Aquaculture Centres in Asia (NACA), Iloilo, 1986).

23 Wyban, J. A. \& Sweeney, J. N. Intensive shrimp production technology $158 \mathrm{High}$ Health Aquaculture Inc, Hawaii, 1991).
24 Lewus, C. B., Kaiser, A. \& Montville, T. J. Inhibition of food-borne bacterial pathogens by bacteriocins from lactic acid bacteria isolated from meat. Appl. Environ. Microb 57, 1683-1688 (1991).

25 Milles, H., Lesser, W. \& Sears, P. The economic implication of bioengineered mastitis control. J. Dairy Sci. 75, 596-605 (1992).

26 Cleveland, J., Montville, T. J., Nes, I. F. \& Chikindas, M. L. Bacteriocins: safe, natural antimicrobials for food preservation. Int. J. Food Microbiol. 71, 1-20 (2001).

27 Foldes, T., Banhegyi, I., Herpai, Z., Varga, L. \& Szigeti, J. Isola on of Bacillus strains from the rhizosphere of cereals and in vitro screening for antagonism against phytopathogenic, food-borne pathogenic and spoilage micro-organisms. J. Appl. Microb 89, 840-846 (2000).

28 Holtmann, G. \& Bremer, E. Thermoprotection of Bacillus subtilis by exogenously provided glycine betaine and structurally related compatible solutes: Involvement of Opu transporters. J. Bacteriol 186, 1683-1693 (2004).

29 Liu, C. H., Chiu, C. S, Ho, P. L. \& Wang, S. W. Improvement in the growth performance of white shrimp, Litopenaeus vannamei, by a protease-producing probiotic, Bacillus subtilis E20, from natto. J. Appl. Microbiol 107, 1031-1041 (2009).

30 Shakiba Zadeh, S. et al. Assessment of growth condition for a candidate probiotic, Shewanella algae, isolated from digestive system of a healthy juvenile Penaeus monodon. Aquacult. Int 18, 1017-1026 (2010).

31 Swain, S. M., Singh, C. \& Arul, V. Inhibitory activity of probiotics Streptococcus phocae $\mathrm{PI} 80$ and Enterococcus faecium MC13 against vibriosis in shrimp Penaeus monodon. World J. Microbiol. Biotechnol 25, 697-703 (2009).

32 Soonthornchai, W. et al. Expression of immune-related genes in the digestive organ of shrimp, Penaeus monodon, after an oral infection by Vibrio harveyi. Dev. Comp. Immunol 34, 19-28 (2010).

33 Vaseeharan, B. \& Ramasamy, P. Control of pathogenic Vibrio spp. by Bacillus subtilis BT23, a possible probiotic treatment for black tiger shrimp Penaeus monodon. Lett. Appl. Microbiol 36, 83-87 (2003).

34 Balcazar, J. L., Rojas-Luna, T. \& Cunningham, D. P. Effect of the addition of four potential probiotic strains on the survival of pacific white shrimp (Litopenaeus vannamei) following immersion challenge with Vibrio parahaemolyticus. J. Invertebr. Pathol 96, 147-150 (2007).

This work is licensed under the Creative Commons Attribution-NonCommercial-No Derivative Works 3.0 Unported License. To view a copy of this license, visit http:// creativecommons.org/licenses/by-nc-nd/3.0/

Supplementary Information accompanies the paper on The Journal of Antibiotics website (http://www.nature.com/ja) 